\title{
2008 and Beyond: The Future of Election Reform in the States-Editor's Introduction
}

$T$ his forum is a unique opportunity to bring social science research to bear on public policy and the practical effects of election reforms in the American states. It is also an opportunity to study America's election system, building on the research of some of the leading scholars working in this area. The American states offer a natural laboratory (a "laboratory of democracy"), with significant variation in the rules, institutions, and procedures governing elections. This forum empirically evaluates what we have learned about the effects of various election reforms in the 50 states. The papers included in this forum were originally presented at a conference hosted by Kent State University's department of political science and which had a title similar to that of this symposium. ${ }^{1}$ The theme is now shared by the conference and this symposium: that the 2008

presidential election will be crucial for American

by

\section{Caroline Tolbert,} University of lowa democracy, especially in light of the apparently related phenomena of decreasing (or flattening) voter participation

rates, low trust in government and political efficacy, alleged procedural irregularities in recent elections, uncompetitive congressional elections or uncontested state legislative elections, and lapses in ethical judgment by politicians in the past decade.

Bruce Cain's overview of this symposium focuses on the importance of election administration and reforms protecting voting integrity; Todd Donovan's conclusion emphasizes the need for more competitive elections as a means to improve representation. Cain's call for reform to improve election administration within the existing system is supported by Paul Gronke, Eva Galanes-Rosenbaum, and Peter A. Miller's study of the effects of convenience voting reforms on voter turnout; by Thad Hall, Quin Monson, and Kelly Patterson's study of the impact of poll-worker training on citizen political efficacy and voter confidence; and by Lonna Atkeson and Kyle Saunders' analysis of how state election administration and voting technology impact voter confidence. Donovan's call for improving representation via competitive elections, enacted through structural reforms of state election systems, garners support from Timothy Werner and Kenneth Mayer's study of the impact of gender on candidates' decision to accept public campaign financing; from Barry Burden's study of how ballot access restrictions impact third-party candidates; and from Michael McDonald's (2007a) typology of state redistricting reforms. These authors consider reforms that might open the election system to improve representation. Other papers presented at the conference, but not included in this symposium because of space constraints include: 1) Beth Rosenson, state conflict of interest laws; 2) Chris Mooney, legislative term limits; 3) Christopher Cooper, multi-member districts; 4) Daniel Smith, ballot initiatives and referenda; and 5) Rob Richie, National Popular Vote Plan.

American elections have been plagued by problems in recent years. By many accounts, the 2000 and 2004 presidential elections were considered the most closely contested of the past century, and yet turnout of the voting-age population was just $55 \%$ (60\% of the votereligible population) (McDonald 2007b). Almost one in every two eligible Americans sits elections out. What are the reasons Americans give for not voting? An October, 2006 Pew survey ${ }^{2}$ found that $58 \%$ reported a lack of knowledge or interest in politics as a reason for not voting ("I sometimes feel I don't know enough about the candidates to vote"). In answering an openended question asking, "What was it that kept you from voting?" in 2004, over $20 \%$ (or one in five) reported they "didn't like the candidates" or were "not interested in politics." Consistent with some literature (Bowler and Donovan forthcoming), it may be uncompetitive elections that pose barriers to voting.

The same survey offers evidence of problems with the integrity of the voting system. The 2006 Pew survey found $68 \%$ of non-voters were "very" or "somewhat confident" that "If you were to vote this November," your vote "would be accurately counted?" But a rather high $32 \%$ reported little or no confidence that their vote would be accurately counted. That is almost one in three Americans who choose not to vote. Confidence in the integrity of the election system may pose barriers to voting.

Although most advanced industrialized nations have universal voter registration, and Europe has progressed rapidly with remote 
Internet voting, less than a dozen states allow Election-Day voter registration, with many requiring registration a month before the election. There are no plans for remote Internet voting in the U.S. at this time. One trend on the horizon is the slow, quiet but steady rise in early voting discussed in this issue by Paul Gronke, Eva Galanes-Rosenbaum, and Peter A. Miller. Up to one-third of residents in Western states now cast votes before the election, either at polling stations or by mail (absentee ballots). These reforms hint at ways to reduce the costs of voting for those interested in elections.

Beyond low turnout, there are obvious examples of election administration failure, including the continued use of lever or punch-card voting machines in an era of widespread computer and Internet use for commerce, business, and even e-government (Mossberger, Tolbert, and McNeal 2007). With the adoption of HAVA (Help Americans Vote Act) the states have witnessed a massive shift toward computerized voting machines, but many hurdles remain. New electronic voting machines that are thrust into an election without adequate administration and poll-worker training are bound to fail. A littleknown feature of election administration is the role of the poll worker, the critical link between voters and the technology they must use to cast a valid vote. Poll workers exert power, including whether to request government photo identification and whether a provisional ballot will be provided, besides providing other means of voter support on Election Day. Thad Hall, Quin Monson, and Kelly Patterson analysis of unique state-survey data of poll workers shows how the training poll workers receive influences the number of polling place administration problems on Election Day. Election administration, the process of ensuring that people have access to vote and that their votes are counted fairly, is of growing importance to the integrity of our system. Lonna Atkeson and Kyle Saunder's analysis of new survey data from the 2006 elections finds that it is at this individual level that voters interface with government, and that interaction, positive or negative, affects their faith in the system. Bruce Cain places a premium on the ability of reforms to improve the integrity of the election system. He also warns of the increasing role of the courts in deciding institutional disputes (dangers of judicialization) and the need for finding "secondbest solutions."

Beyond voting integrity, structural problems with America's electoral system remain. The failure to elect a president who won both the popular vote and the Electoral College vote in the 2000 elections was widely derided and has lead to repeated calls for direct election of that office. ${ }^{3}$ The 2000 election was decided by the courts, the least democratic branch of government. Just one president has been elected since 1988 with the support of a majority of those who voted (Donovan and Bowler 2004, 9). With more independent voters and third parties, increasingly a majority of voters in presidential elections are electoral losers. In 1996, when Bill Clinton was reelected with just $43 \%$ of the popular vote, Reform Party (Ross Perot) and Republican voters (Bob Dole) alike were losers, even though they constituted $57 \%$ of the electorate. In the 2000 presidential elections, Democratic voters (Al Gore) and Ralph Nader voters were electoral losers, and combined they outnumbered George W. Bush voters; Bush was elected to the White House with a minority of the popular vote.

Our two-party system is based on single-member districts that make it virtually impossible for third- or fourth-party candidates to win election to Congress or even state legislatures. And yet more than one-third of Americans identify as independents. How is our election system representing the moderates and this vast sea of independent voters, when Congress is increasingly polarized by representatives from the extreme Right and Left? Some believe the failure to represent the ideological middle signals more fundamental structural problems with our election system. Todd Donovan's contribution in this forum focuses on problems of representation and offers some possible solutions.

A lack of competition signals another malaise of our political system. In the 2004 elections, just 14 U.S. House seats were considered really competitive (vote margin of $5 \%$ or less). That is a mere $3 \%$ of U.S. House races. Reelection rates to Congress hover at $98 \%$, while over one-third of state legislative elections are uncontested. Gerrymandered districts or incumbent protection maps dominate the states. If elections are not-competitive, or worse uncontested, fewer active campaigns will produce less political information. Voters will have fewer choices and less incentive to learn the game of politics, to become informed and knowledgeable, or to vote. In this symposium Michael McDonald analyzes state-level redistricting plans and alternatives to partisan gerrymandering, while Timothy Werner and Kenneth Mayer show the effects of public financing laws on the number and gender diversity of candidates running for state legislative seats. Barry Burden explains why some states have more third parties running for office than others, and why third parties may be beneficial. These papers look at reforms to make elections more competitive and increase the number of candidates/parties running for office.

Cain's introduction and Donovan's conclusion provide two different broad perspectives for how these pieces of the reform puzzle fit into a comprehensive framework of election system reform in the U.S. This unique integration is missing in the current literature, which tends to focus on individual reforms in isolation. This symposium provides organization for a growing subfield, but also offers empirical evidence of what does and does not work.

A century ago, progressive reformers adopted institutional reforms of state election systems which resulted in women's suffrage, the direct election of U.S. senators, direct democracy, and much more. Concerned with big business in the first Gilded Age, progressive reformers lobbied state legislatures for sweeping changes in government rules and institutions. By many measures they succeeded in adopting laws to update and modernize government for an industrial twentieth century. At the beginning of the twenty-first century, we are again in a period of repeated calls for a new progressivism to reevaluate America's electoral institutions (Tolbert 2003). We may take varying paths to achieve modernization, but they are all part of one reform agenda.

\section{Notes}

1. "2008 and Beyond: The Future of Election and Ethics Reform in the States." Columbus, OH, January 16-18, 2007. Hosted by Kent State University's Department of Political Science and Professor Vernon Sykes. Available at: http://dept.kent.edu/columbus/symposium/.

2. Pew Research Center for the People and the Press and the Associated Press, Early October 2006 Turnout Survey. Random digit dialed telephone survey of adults age 18 and older from the continental United States. Conducted by the Princeton Research Associates. $\mathrm{N}=1,773$.

3. One such plan is the National Popular Vote Plan (see Fairvote.org) 


\section{References}

Atkeson, Lonna Rae, and Kyle L. Saunders. 2007. “The Effect of Election Administration on Voter Confidence: A Local Matter?" PS: Political Science and Politics 40 (October): 655-60.

Bowler, Shaun, and Todd Donovan. Forthcoming. "Barriers to Participation for Whom? Regulations on Voting and Uncompetitive Elections." In Mobilizing Democracy, eds. Margaret Levi, Jim Johnson, Jack Knight, and Susan Stokes. New York: Russell Sage Foundation.

Burden, Barry C. 2007. "Ballot Regulations and Multiparty Politics in the States." PS: Political Science and Politics 40 (October): 669-73.

Cain, Bruce E. 2007. "Reform Studies: Political Science on the Firing Line." PS: Political Science and Politics 40 (October): 635-8.

Donovan, Todd. 2007. "A Goal for Reform: Make Elections Worth Stealing." PS: Political Science and Politics 40 (October): 681-6.

Donovan, Todd, and Shaun Bowler. 2004. Reforming the Republic: Democratic Institutions for the New America. Upper Saddle River, NJ: Pearson Prentice Hall.

Gronke, Paul, Eva Galanes-Rosenbaum, and Peter A. Miller. 2007. "Early Voting and Turnout." PS: Political Science and Politics 40 (October) 639-45.

SYMPOSIUM AUTHORS' BIOS

Lonna Rae Atkeson is professor of political science and Regents lecturer at the University of New Mexico. She studies public opinion and political behavior, emphasizing the role contextual factors play in shaping attitudes and behaviors of political actors.

Barry C. Burden is professor of political science at the University of Wisconsin-Madison. He has published widely in American politics, particularly in the areas of electoral politics, public opinion, and congressional behavior. His most recent publication is Personal Roots of Representation (Princeton University Press, 2007).

Bruce E. Cain is Heller Professor of Political Science at the University of California, Berkeley and director of the University of California Washington Center. His writings include The Reapportionment Puzzle (1984), The Personal Vote (1987), written with John Forejohn and Morris Fiorina, and Congressional Redistricting (1991), with David Butler. Professor Cain has served as a polling consultant for state and senate races to Fairbank, Canapary and Maulin (1985-86); redistricting consultant to (among others) the Justice Department, 1989; Los Angeles County, 1991; San Diego Citizens Commission on Redistricting, 2001; City and County of San Francisco, 2002; and Special Master for a three judge panel, Arizona State Legislative Redistricting, 2002.

Todd Donovan is professor of political science at Western Washington University. His research interests include representation and election systems, and political behavior. His co-authored books include Loser's Consent: Elections and Democratic Legitimacy (Oxford University Press, 2005), Reforming the Republic: Democratic Institutions for the New America (Prentice Hall, 2004), and Electoral Reform and Minority Representation (Ohio State University Press, 2003).

Eva Galanes-Rosenbaum is associate director of the Early Voting Information Center (EVIC) at Reed College.

Paul Gronke is a professor of political science at Reed College and director of the Early Voting Information Center (EVIC).

Thad Hall is assistant professor of political science and a research fellow in the Institute of Public and International Affairs at the University of Utah. His book Electronic Elections (with R. Michael Alvarez) is forthcoming from Princeton University Press.
Hall, Thad, Quin Monson, and Kelly Patterson. 2007. "Poll Workers and the Vitality of Democracy: An Early Assessment." PS: Political Science and Politics 40 (October): 647-54.

McDonald, Michael P. 2007a. "Regulating Redistricting." PS: Political Science and Politics 40 (October): 675-9.

. 2007b. "United State Election Project." Available at: http:// elections.gmu.edu/voter_turnout.htm.

Mossberger, Karen, Caroline Tolbert, and Ramona McNeal. 2007. Digital Citizenship: The Internet, Society and Participation. Cambridge: MIT Press.

Tolbert, Caroline. 2003. "Direct Democracy and Institutional Realignment in the American States." Political Science Quarterly 118 (3): 467-89.

Werner, Timothy, and Kenneth R. Mayer. 2007. "Public Election Funding, Competition, and Candidate Gender." PS: Political Science and Politics 40 (October): 661-7.

Kenneth R. Mayer is professor of political science at the University of Wisconsin-Madison, and director of the Wisconsin Campaign Finance Project.

Michael P. McDonald is associate professor at George Mason University and non-resident senior fellow at the Brookings Institution. He has been involved in redistricting litigation in five states. The Joyce Foundation is generously supporting his current research into redistricting reform.

Peter A. Miller is the research director of the Early Voting Information Center (EVIC) at Reed College.

J. Quin Monson is assistant professor of political science and assistant director of the Center for the Study of Elections and Democracy at Brigham Young University. His research interests include public opinion, survey research methods, and campaigns and elections.

Kelly D. Patterson is professor of political science and director of the Center for the Study of Elections and Democracy at Brigham Young University. His teaching and research interests include public opinion, elections, and voting behavior.

Kyle L. Saunders is associate professor of political science at Colorado State University. Saunders studies American political attitudes, political behavior, elections, and political parties.

Caroline Tolbert is associate professor of political science at the University of lowa. She is author or coauthor of numerous articles on voting, elections and representation, direct democracy, subnational politics, technology and politics, and race and turnout. She is coauthor (with Daniel Smith) of Educated by Initiative: The Effects of Direct Democracy on Citizens and Political Organizations in the American States (University of Michigan, 2004). She is coeditor (with Todd Donovan and Shaun Bowler) of Citizens as Legislators: Direct Democracy in the United States (Ohio State University Press, 1998) and coauthor (with Karen Mossberger) of Digital Citizenship: The Internet, Society and Participation (MIT Press, 2007) and Virtual Inequality: Beyond the Digital Divide (Georgetown University Press, 2003).

Timothy Werner is a Ph.D. candidate in political science at the University of Wisconsin-Madison. His dissertation examines the political motivations for self-regulation by American businesses. 